\title{
The effect of mepivacaine on swine lingual, pulmonary and coronary arteries
}

\author{
Kenichi Satoh ${ }^{1 *}$, Mami Chikuda ${ }^{1}$, Ayako Ohashi $^{1}$, Miho Kumagai ${ }^{2}$, Masahito Sato ${ }^{1}$ and Shigeharu Joh ${ }^{1}$
}

\begin{abstract}
Background: Although mepivacaine has a known biphasic action on the aortic and coronary artery in several animal species, its effects on the lingual and pulmonary artery are not well understood and it is not yet known whether mepivacaine produces vasoconstriction in these vessels. The present study aims to investigate the direct effects of mepivacaine on swine lingual, pulmonary and coronary arterial endothelium-denuded rings.

Methods: Artery rings were perfused with isotonic $40 \mathrm{mM} \mathrm{KCl}$ until a stable constricted plateau was reached. The rings were then perfused with isotonic $40 \mathrm{mM} \mathrm{KCl}$ plus a particular concentration of mepivacaine $(0.4 \mu \mathrm{M}, 4.0 \mu \mathrm{M}$, $40 \mu \mathrm{M}, 0.4 \mathrm{mM}$ and $4.0 \mathrm{mM}$ ). The isometric tension strengths in each experiment were normalized to the strength of the isometric tension immediately before mepivacaine perfusion and expressed as a percentage.

Results: Mepivacaine at 0.4 to $40 \mu \mathrm{M}$ did not significantly alter $40 \mathrm{mM} \mathrm{KCl}$-induced contraction in the lingual, pulmonary and coronary arterial rings. In contrast, mepivacaine at $4 \mathrm{mM}$ produced attenuated vasoconstriction in the lingual, pulmonary and coronary arterial compared with isotonic $40 \mathrm{mM} \mathrm{KCl}$.

Conclusions: Mepivacaine produced vasoconstriction at lower concentrations, followed by attenuated vasoconstriction at higher concentrations on swine lingual, pulmonary and coronary arterial endothelium-denuded rings. Mepivacaine $(4 \mu \mathrm{M})$ appeared to increase isotonic $40 \mathrm{mM} \mathrm{KCl}$-induced contraction, followed by attenuated vasoconstriction at $4 \mathrm{mM}$. Dentists using $3 \%$ mepivacaine should take into consideration that the risk of complications may be increased if more than six mepivacaine cartridges are used in dental treatment or minor surgery, or if over $15 \mathrm{ml}$ of mepivacaine is administered to a patient with cardiovascular complications during general anesthesia for oral maxillofacial surgery.
\end{abstract}

Keywords: Local anesthetic, Isometric tension, Vasocontractive activity, Swine artery

\section{Background}

Amino-amide local anesthetics including mepivacaine, lidocaine, ropivacaine and levobupivacaine have a biphasic action on the smooth muscle of peripheral vessels, ranging from vasoconstriction to vasodilation depending on the concentration used $[3,11,16]$. Mepivacaine essentially has mild vasoconstrictive activity in vessels [15]. Although mepivacaine has a biphasic action on the aortic or coronary artery in several animal species $[12,18,20]$, there are few studies examining the effects of mepivacaine on other peripheral vessels, such as the craniofacial arteries or the pulmonary artery.

\footnotetext{
* Correspondence: satoken@iwate-med.ac.jp

${ }^{1}$ Division of Dental Anesthesiology, Department of Reconstructive Oral and Maxillofacial Surgery, School of Dentistry, Iwate Medical University, 1-3-27 Chuo-dori, Morioka, Iwate 020-8505, Japan

Full list of author information is available at the end of the article
}

Dentists typically use mepivacaine without vasoconstrictors for short-duration dental procedures and oral maxillofacial surgery. Regarding absorption rates and blood kinetics of mepivacaine, the maximum concentration in plasma was $4.65 \pm 0.47 \mu \mathrm{g} / \mathrm{ml} 15 \mathrm{~min}$ after administration of $25 \mathrm{ml}$ of $2 \%$ mepivacaine to epidural blocks, and $3.53 \pm 0.39 \mu \mathrm{g} / \mathrm{ml} 25 \mathrm{~min}$ after administration of $25 \mathrm{ml}$ of $2 \%$ mepivacaine to peripheral nerve brachial plexus blocks [19]. In dental treatment, mean peak serum levels of $0.69 \mu \mathrm{g} / \mathrm{ml}$ were reached when one dental cartridge $(1.8 \mathrm{ml})$ containing $54 \mathrm{mg}$ mepivacaine was infiltrated at the mucosa on the apex of the right maxillary second bicuspid, while the mean peak levels were $1.31 \mu \mathrm{g} / \mathrm{ml}$ when two dental cartridges $(3.6 \mathrm{ml})$ containing a total of $108 \mathrm{mg}$ mepivacaine were infiltrated at the same mucosa [6]. The rate and degree of diffusion is governed by the degree of plasma protein 
binding, the degree of ionization, and the degree of lipid solubility. Local anesthetics appear to be inversely related to the degree of plasma protein binding, as only the free, unbound drug is available; mepivacaine is approximately $77 \%$ bound to plasma proteins [2]. The most commonly encountered acute adverse experiences which demand immediate countermeasures are related to the central nervous system and the cardiovascular systems. These adverse experiences are generally doserelated and due to high plasma levels. In additional to systemic dose-related toxicity, an intentional subarachnoid injection of drug during the intended performance of caudal or lumbar epidural block or nerve blocks near the vertebral column may result in underventilation or apnea. Toxic blood concentrations depress cardiac conduction and excitability, which may lead to atrioventricular block and ultimately to cardiac arrest [17].

The effects of mepivacaine on local regions such as craniofacial and pulmonary arteries are not well-known. Mepivacaine has such a diversity of effects on smooth muscle that we cannot guess its effects on any particular smooth muscle. Although mepivacaine has a biphasic action on the aortic or coronary artery in several animal species, its effects on the lingual or the pulmonary artery are not well understood. It has also not yet been fully investigated whether mepivacaine produces vasoconstriction in these vessels, and if mepivacaine does produce vasoconstricion in these vessels, the concentrations producing vasoconstriction have not yet been determined. The present study aims to clarify these issues. Thus, the present study was designed to further investigate the direct effects of mepivacaine on these vessels in vitro using swine lingual and pulmonary arterial rings and compared with the coronary artery.

\section{Methods}

This study was approved by the Institutional Review Committee on the Ethics of Animal Experiments of Iwate Medical University. All experiments were conducted in accordance with the Institutional Animals Care and Use Committee guidelines.

\section{Reagents and solutions}

Mepivacaine hydrochloride was purchased from SigmaAldrich Corp. (St. Louis, USA). All other chemicals were obtained from Wako Pure Chemical Industries (Osaka, Japan). In all experiments, air-equilibrated Hank's balanced salt solution (HBSS) was used to maintain the arteries under resting conditions. HBSS was made up of $137 \mathrm{mM} \mathrm{NaCl}, 5.4 \mathrm{mM} \mathrm{KCl}, 0.8 \mathrm{mM} \mathrm{MgSO}_{4}$, $1.26 \mathrm{mM} \mathrm{CaCl}, \quad 0.34 \mathrm{mM} \mathrm{Na}_{2} \mathrm{HPO}_{4}, 0.44 \mathrm{mM}$ $\mathrm{KH}_{2} \mathrm{PO}_{4}, 4.2 \mathrm{mM} \mathrm{NaHCO}$, and $5.55 \mathrm{mM}$ glucose ( $\mathrm{pH}$ 7.34). All other salt solutions used as perfusate were made by modifying HBSS. Isotonic 40 or $100 \mathrm{mM}$
$\mathrm{KCl}$ solution was prepared by replacing the $\mathrm{NaCl}$ in the HBSS solution with an equimolar amount of $\mathrm{KCl}$. Each isotonic $40 \mathrm{mM} \mathrm{KCl}$ alone and isotonic $40 \mathrm{mM}$ $\mathrm{KCl}$ plus mepivacaine treatment was made by adding the component agents into the isotonic $40 \mathrm{mM} \mathrm{KCl}$ immediately before use.

\section{Artery ring preparation and isometric tension measurement}

Fresh swine tongues, lungs and hearts were obtained from a local abattoir. A segment of the lingual artery at the proximal region of the tongue, third generation pulmonary artery and left coronary artery was dissected out. After the adventitia was removed, the lingual artery and coronary artery segments (approximately $2 \mathrm{~mm}$ in diameter) and the pulmonary artery segments (approximately $2-3 \mathrm{~mm}$ in diameter) were cut into $3-\mathrm{mm}$-long rings, and the lumen surface was rubbed gently against a thin arm of stainless steel tweezers to remove the endothelium [7]. It was confirmed that $3 \mu \mathrm{M}$ acetylcholineinduced relaxation of the artery rings preconttracted with $40 \mathrm{mM} \mathrm{KCl}$. The artery rings were kept in HBSS at $5{ }^{\circ} \mathrm{C}$ until used for measurement.

An artery ring was held with two tungsten needles in the perfusion chamber (containing $3 \mathrm{ml}$ of perfusate). One needle was fastened to a displacement transducer (Type UL-2GR, Minebea Co., Fujisawa, Japan), and the other to a micromanipulator. The solution was bubbled with a mixture of $95 \% \mathrm{O}_{2}$ and $5 \% \mathrm{CO}_{2}$, and held at a temperature of $37^{\circ} \mathrm{C}$ and flow rate of $1.6 \mathrm{ml} / \mathrm{min}$ with a peristaltic pump (SMP-23, Tokyo Rikakikai Co., Tokyo, Japan). As the strength of contraction did not change when the resting tone was $3-7 \mathrm{mN}$, the artery rings were extended to give a resting tone of approximately 5 $\mathrm{mN}$ and immediately tested for contractility by two 2.5 min perfusions with isotonic $100 \mathrm{mM} \mathrm{KCl}$ separated by a 10 min HBSS perfusion. After a 30 min HBSS perfusion, artery rings were perfused with isotonic $40 \mathrm{mM}$ $\mathrm{KCl}$. When a stable constricted plateau was reached with isotonic $40 \mathrm{mM} \mathrm{KCl}$, an isotonic $40 \mathrm{mM} \mathrm{KCl}$ solution containing mepivacaine at concentrations of $0.4 \mu \mathrm{M}, 4.0 \mu \mathrm{M}, 40 \mu \mathrm{M}, 0.4 \mathrm{mM}$ and $4.0 \mathrm{mM}$ was perfused. Each concentration was perfused for $5 \mathrm{~min}$. HBSS perfusion was always performed after all drug perfusions were completed. Isometric tension was detected using a displacement transducer, and signals detected were amplified with a carrier amplifier (CSD-815 Digital indicator, Minebea Co., Fujisawa, Japan) and recorded with a Powerlab 16/30 $\mathrm{T}$ data acquisition system (ADInstruments, Bella Vista, Australia). The isometric tension strengths in each experiment were normalized to the strength of the isometric tension immediately before mepivacaine perfusion. Vascular response induced by mepivacaine in arterial rings was expressed as 
the percentage of the contraction induced by isotonic $40 \mathrm{mM} \mathrm{KCl}$.

\section{Statistical analyses}

Dilation was determined by measuring the cumulative reduction in induced tone in the arterial segments, and was expressed as the percentage of the contraction induced by isotonic $40 \mathrm{mM} \mathrm{KCl}$. A value of $0 \%$ indicates initial resting tension $(5 \mathrm{mN})$, and a value of $100 \%$ indicates the isometric tension generated by exposure to isotonic $40 \mathrm{mM}$ $\mathrm{KCl}$. Values greater than $100 \%$ indicate that contraction occurred in response to mepivacaine. Values are presented as mean \pm standard deviation. Statistical analysis was performed using SPSS, version 11.0 (SPSS, Chicago, IL, USA). The Shapiro-Wilk test was used for normality, and Bartlett's test was used for homogeneity of variance. Repeat measure analysis of variance (ANOVA) followed by Bonferroni's post-test was performed. Differences were considered significant at $\mathrm{P}<.05$.

\section{Results}

There was no response induced by mepivacaine in lingual, pulmonary and coronary arterial rings under resting conditions in HBSS (Fig. 1). Mepivacaine resulted in dilation of the swine lingual, pulmonary and coronary arterial rings that were maintained in a stable, constricted state; typical traces of the changes in isometric tension in response to increasing mepivacaine concentrations $(0.4 \mu \mathrm{M}$ to $4 \mathrm{mM})$ are shown in Figs 2, 3 and 4. Dose response curves at these concentrations are shown in Fig. 5. Mepivacaine at 0.4 to $40 \mu \mathrm{M}$ did not significantly alter $40 \mathrm{mM} \mathrm{KCl-}$ induced contraction in the lingual, pulmonary and coronary arterial rings (Table 1). In contrast, the highest concentration of mepivacaine $(4 \mathrm{mM})$ produced attenuated vasoconstriction. There were significant differences between the effects of the control solution $(40 \mathrm{mM} \mathrm{KCl})$ and the effect of $4 \mathrm{mM}$ mepivacaine on the lingual artery, $400 \mu \mathrm{M}$ and $4 \mathrm{mM}$ mepivacaine on the pulmonary artery, and $4 \mathrm{mM}$ mepivacaine on the coronary artery.

\section{Discussion}

Mepivacaine produced vasoconstriction at lower concentrations, followed by attenuated vasoconstriction at higher concentrations on swine lingual, pulmonary and coronary arterial endothelium-denuded rings under isotonic conditions. Numerous studies have demonstrated that amino-amide local anesthetic agents can exhibit biphasic vascular effects, with contraction at low concentrations and decreased contraction or even dilation at high concentrations reported in aortic or coronary arterial rings in several animal species [4-6]. The biphasic vascular effect is a common characteristic of amino-amide local anesthetic agents that has been extensively studied $[1,4,10]$. However, biphasic activity has been largely reported in rat aortic or coronary arteries, and to our knowledge there are no studies examining the effects of mepivacaine on craniofacial arteries such as the lingual artery. In this study, we found that mepivacaine appeared

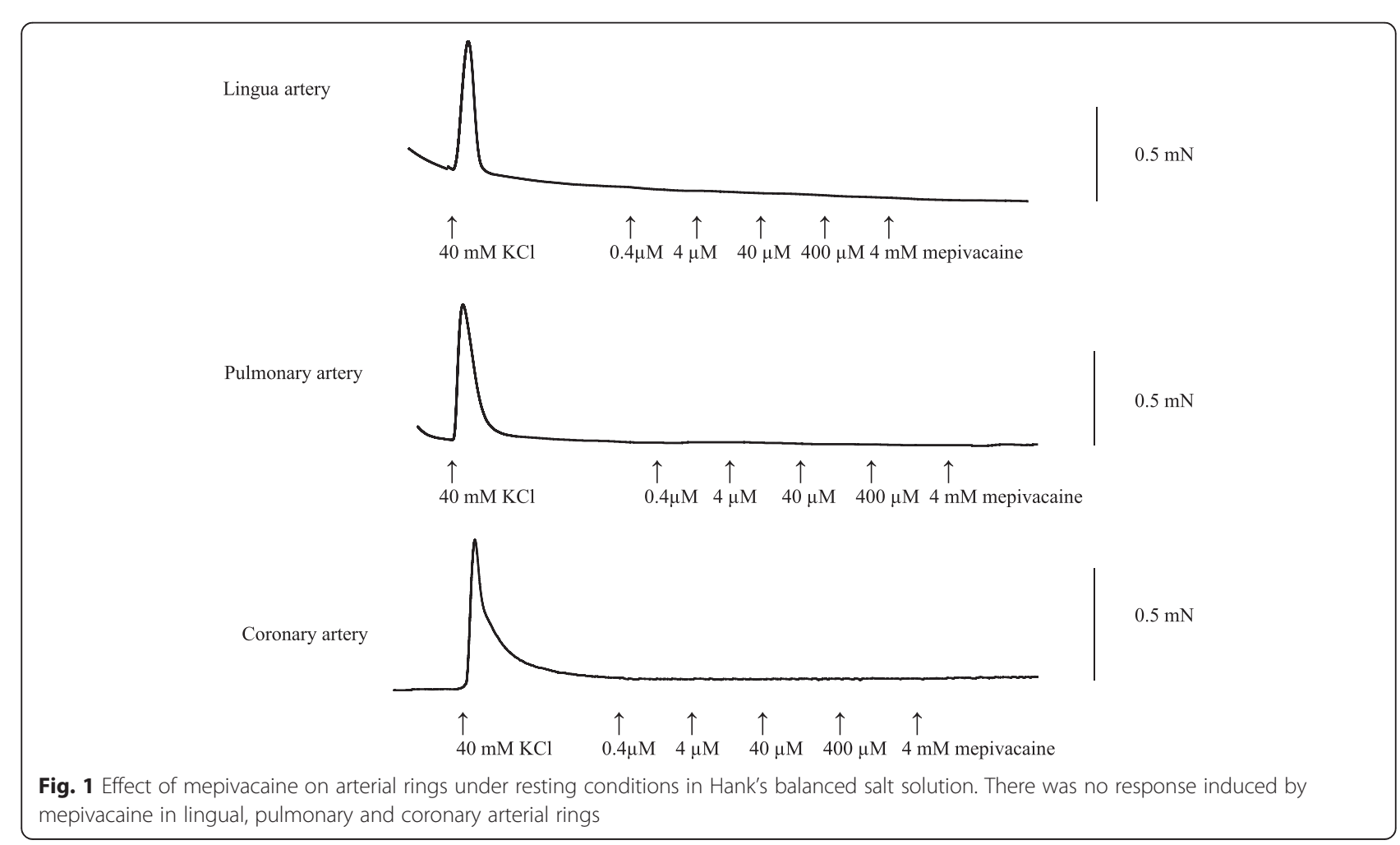



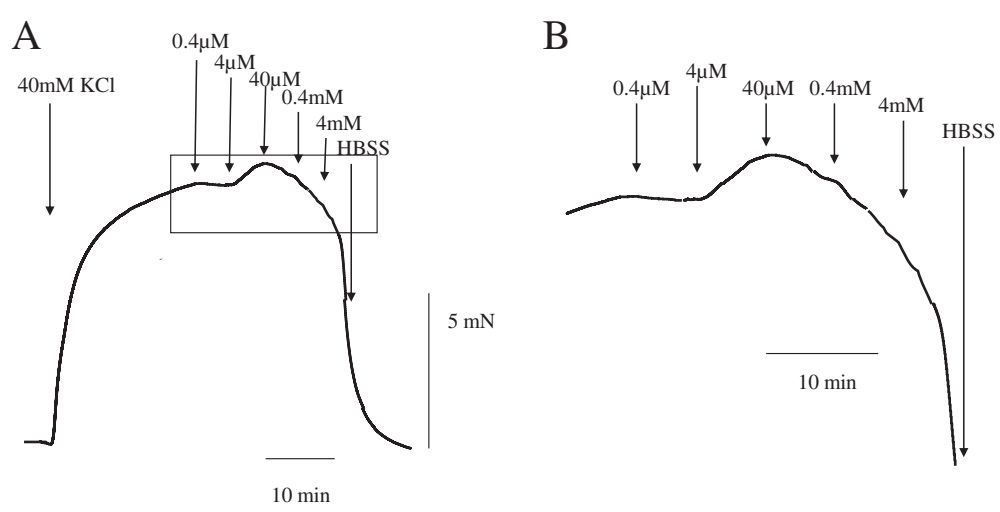

Fig. 2 A typical trace showing the effect of mepivacaine on lingual artery ring contraction induced with $40 \mathrm{mM} \mathrm{KCl}$. a Representative recording of the mepivacaine-induced contraction. $\mathbf{b}$ Enlarged view of a square portion of (a)

to increase isotonic $40 \mathrm{mM} \mathrm{KCl}$-induced contraction at $4 \mu \mathrm{M}$ concentration, caused dilation at higher concentrations from $40 \mu \mathrm{M}$ to $4 \mathrm{mM}$ in the lingual and coronary artery, and dose-dependent dilation from $40 \mu \mathrm{M}$ to $4 \mathrm{mM}$ in the pulmonary artery. We did not investigate the mechanism(s) of smooth muscle constriction and dilation by mepivacaine in this study. A previous report investigating the effect of mepivacaine on the isolated rat aorta found that verapamil and calcium-free Krebs solution attenuated mepivacaine-induced contraction of the endothelium-denuded aorta [16]. Thus, calcium influx via voltage-operated calcium channel (VOCC) activation by low concentrations of mepivacaine may trigger the initial contraction, while a high concentration of mepivacaine had an inhibitory effect on the VOCCs in vascular smooth muscle [16].

Mepivacaine $(4 \mu \mathrm{M})$ appeared to increase isotonic $40 \mathrm{mM} \mathrm{KCl}$-induced contraction, followed by attenuated vasoconstriction at $4 \mathrm{mM}$ compared with isotonic $40 \mathrm{mM}$
$\mathrm{KCl}$-induced contraction. Similarly, a previous study found that mepivacaine produced contraction at low concentrations $\left(1 \times 10^{-3}\right.$ and $\left.3 \times 10^{-3} \mathrm{~mol} / \mathrm{L}\right)$ followed by dilation at a high concentration $\left(1 \times 10^{-2} \mathrm{~mol} / \mathrm{L}\right)$ in the rat aorta [16]. It has been reported that contraction induced by $\mathrm{KCl}$ and phenylephrine is attenuated in the presence of mepivacaine $\left(10^{-3} \mathrm{M}\right)$ in isolated endothelium-denuded rat aorta [10]. In contrast, lower concentrations of mepivacaine $\left(10^{-9}-10^{-5} \mathrm{M}\right)$ did not evoke any changes in tension in isolated ciliary artery rings [8]. Furthermore, it was reported that in response to transmural stimulation, to the tension of rabbit aortic strips was not altered by mepivacaine in concentrations raging from $5 \times 10^{-4}$ to $2 \times 10^{-3} \mathrm{M}$ [9]. In the present study, administration of 4.0 $\mu \mathrm{M}$ mepivacaine appeared to increase isotonic $40 \mathrm{mM} \mathrm{KCl}$-induced contraction in swine lingual, pulmonary and coronary arterial rings, which is a lower concentration than those previously reported. The reasons for these differences in the mepivacaine concentration are

\section{A}

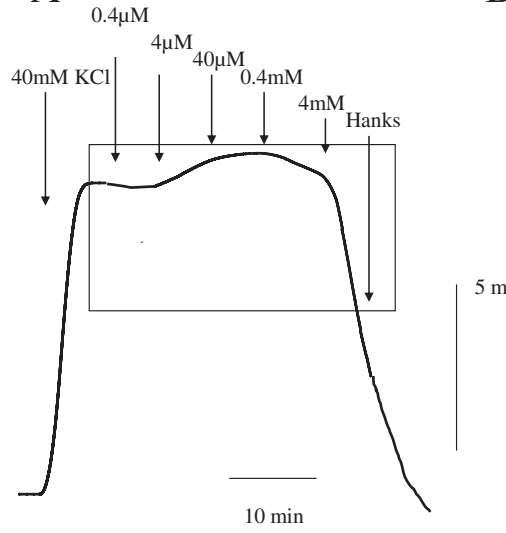

B

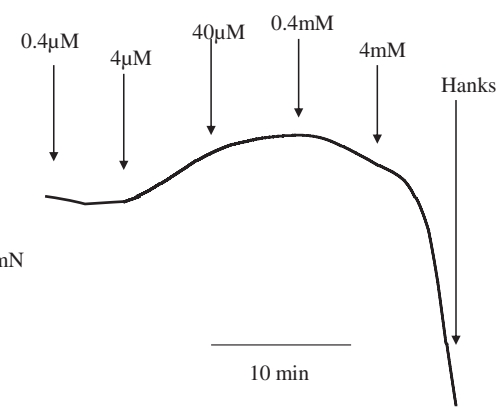

Fig. 3 A typical trace showing the effect of mepivacaine on pulmonary artery ring contraction induced with $40 \mathrm{mM} \mathrm{KCl}$. a Representative recording of the mepivacaine-induced contraction. $\mathbf{b}$ Enlarged view of a square portion of (a) 


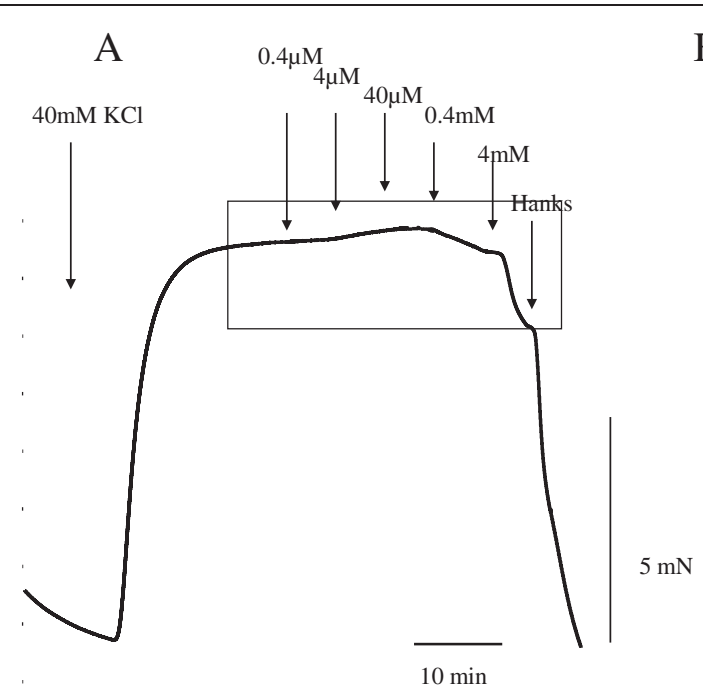

B

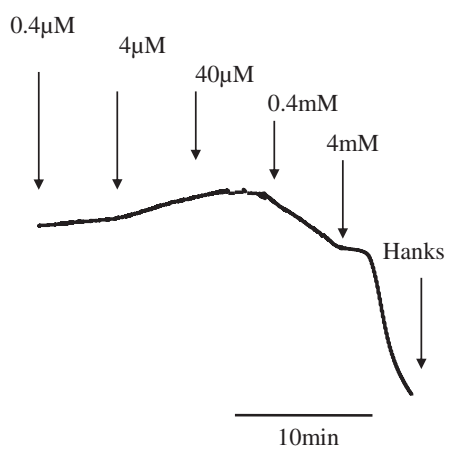

Fig. 4 A typical trace showing the effect of mepivacaine on coronary artery ring contraction induced with $40 \mathrm{mM} \mathrm{KCl}$. a Representative recording of the mepivacaine-induced contraction. $\mathbf{b}$ Enlarged view of a square portion of (a)

unknown, but may relate to differences in species and location [16].

Our previous study suggested that lidocaine at low concentrations produced vasoconstriction in swine lingual and pulmonary arteries, while vasodilation was seen at higher lidocaine concentrations of $1 \mu \mathrm{g} / \mathrm{ml}$ [14]. Perlmutter reported that a lidocaine concentration of $10 \mu \mathrm{g} / \mathrm{ml}$ caused mild vasoconstriction in the porcine coronary artery [12]. Therefore we used mepivacaine at $0.4 \mu \mathrm{M}, 4.0 \mu \mathrm{M}, 40 \mu \mathrm{M}, 0.4 \mathrm{mM}$ and $4.0 \mathrm{mM}$ concentrations as these are almost equivalent to $0.11 \mu \mathrm{g} / \mathrm{ml}, 1.1 \mu \mathrm{g} / \mathrm{ml}, 11 \mu \mathrm{g} / \mathrm{ml}, 110 \mu \mathrm{g} / \mathrm{ml}$, and $1,100 \mu \mathrm{g} / \mathrm{ml}$ concentrations.
The circulating levels of mepivacaine after dental injections have been previously studied. Mean peak serum levels of $0.69 \mu \mathrm{g} / \mathrm{ml}$ were reported when one dental cartridge containing $54 \mathrm{mg}$ mepivacaine was infiltrated at the mucosa on the apex of the right maxillary second bicuspid, while the mean peak levels were $1.31 \mu \mathrm{g} / \mathrm{ml}$ when two dental cartridges containing $108 \mathrm{mg}$ mepivacaine were infiltrated at the same mucosa [6]. It is thought that the concentration of mepivacaine encountered in the clinical setting is approximately $77 \%$ protein-bound, and the rest is free in plasma. If approximately $77 \%$ of lidocaine is bound to plasma proteins, we would assume that only the $23 \%$ free in plasma would affect vascular muscle

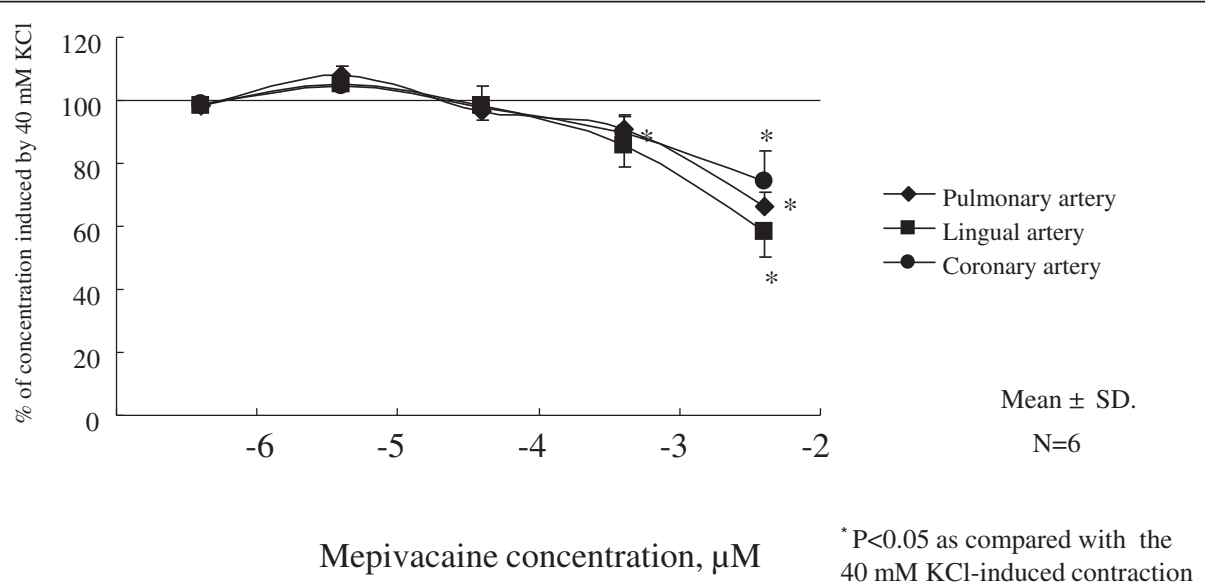

Fig. 5 Dose-dependent response of mepivacaine on lingual, pulmonary and coronary vasorelaxation. Endothelium-denuded lingual, pulmonary and artery rings were challenged with a cumulative dose of mepivacaine. Tension was determined by isometric force transduction, and is expressed as a percentage of the $40 \mathrm{mM} \mathrm{KCl}$-induced contraction $(N=6)$. N indicates the number of arterial rings 
Table 1 Effects of mepivacaine on lingual, pulmonary and coronary artery

\begin{tabular}{llll}
\hline $\begin{array}{l}\text { Mepivacaine } \\
(\mu \mathrm{M})\end{array}$ & $\begin{array}{l}\text { Lingual } \\
\text { artery }(\%)\end{array}$ & $\begin{array}{l}\text { Pulmonary } \\
\text { artery }(\%)\end{array}$ & $\begin{array}{l}\text { Coronary } \\
\text { artery }(\%)\end{array}$ \\
\hline $40 \mathrm{mM} \mathrm{KCl}$ & 100 & 100 & 100 \\
0.4 & $98.3 \pm 1.4$ & $98.3 \pm 1.2$ & $99.0 \pm 0.9$ \\
4 & $108.2 \pm 2.6$ & $105.1 \pm 2.6$ & $103.1 \pm$ \\
40 & $96.6 \pm 6.4$ & $98.1 \pm 3.0$ & $98.0 \pm 4.6$ \\
400 & $90.6 \pm 4.6$ & $85.8 \pm 5.2^{*}$ & $90.0 \pm 6.8$ \\
4000 & $66.1 \pm$ & $58.5 \pm 5.0^{*}$ & $74.1 \pm 8.2^{*}$ \\
& $10.2^{*}$ & & \\
\hline
\end{tabular}

Data are mean \pm SD. Values are expressed as the percentage of contraction induced by isotonic $40 \mathrm{mM} \mathrm{KCl}$

${ }^{*} \mathrm{P}<0.05$ as compared with the $40 \mathrm{mM} \mathrm{KCl}$-induced contraction

directly [2]. Hence, when one dental cartridge containing $54 \mathrm{mg}$ mepivacaine is infiltrated into the mucosa, there would presumably be mean peak levels of $0.16 \mu \mathrm{g} / \mathrm{ml}$ free in plasma. In the present study, $4 \mu \mathrm{M}(1.1 \mu \mathrm{g} / \mathrm{ml})$ mepivacaine appeared to increase isotonic $40 \mathrm{mM} \mathrm{KCl}$-induced contraction in swine lingual, pulmonary and coronary arterial rings. Thus, if we consider the amount of free plasma mepivacaine when dentists infiltrate six to eight dental mepivacaine cartridges into the oral mucosa, mepivacaine-induced vasoconstriction may occur in the orofacial, pulmonary and coronary arteries. An increase in the plasma concentration of mepivacaine would increase the concentration of free plasma mepivacaine. Therefore, we think it is possible that mepivacaine-induced vasoconstriction may occur in orofacial and pulmonary arteries when less than six to eight mepivacaine cartridges are infiltrated into the oral mucosa. In dental treatment, we usually use one or two $3 \%$ mepivacaine cartridges, but occasionally more than six cartridges are used for minor surgery or extraction. Dentists are educated to avoid using lidocaine with adrenaline cartridges for patients with cardiovascular complications, especially with a past history of vasospasm, hypertension, and heart failure; therefore in these patients local anesthetic without adrenaline is used, for example mepivacaine or prilocaine with felypressin, to prevent side effects induced by adrenaline. In patients with cardiovascular complications, if more than six cartridges of $3 \%$ mepivacaine are used in dental treatment or minor surgery, or over $15 \mathrm{ml}$ at a time during general anesthesia for oral maxillofacial surgery, this could potentially increase the risks of complication by mepivacaine-induced vasoconstriction in the lingual, coronary and pulmonary arteries. In addition, mepivacaine-induced contraction may be attenuated in patients taking calcium channel antagonists for the management of hypertension, leading to a short duration of mepivacaine-induced analgesia [13]. Mepivacaine-induced vasoconstriction may contribute to pale skin color, decreased cutaneous blood flow, attenuated capillary blood flow increase, attenuated reactive hyperthermia observed after analgesia induced by mepivacaine, and intermediate duration of mepivacaine-induced analgesia [16].

There are some limitations to our study. Amino-amide local anesthetics release nitric oxide, which produces vasodilation of isolated vessels [3, 11, 16]; hence, mepivacaine-induced vasoconstriction is attenuated in endothelium-intact vessels compared with endotheliumdenuded vessels. As we used endothelium-denuded arterial rings in the current study, mepivacaine-induced vasoconstriction would be attenuated in an in vivo vessel with its endothelium intact. In addition, the data in this study are based on $n=6$, which by all accounts is a small sample size. However, despite the small sample size and insufficient power analysis, we believe that the data provide accurate and reliable information on the effect of mepivacaine on arterial rings, and the findings are useful for further investigation of craniofacial arteries. Further research needs to be done to investigate whether our in vitro results correlate with real-life situations.

\section{Conclusions}

This study showed that a low concentration of mepivacaine produced vasoconstriction, followed by attenuated vasoconstriction at higher concentrations on swine lingual, pulmonary and coronary arterial endotheliumdenuded rings. It also showed that mepivacaine $(4 \mu \mathrm{M})$ appeared to increase isotonic $40 \mathrm{mM} \mathrm{KCl}$-induced contraction, followed by attenuated vasoconstriction at $4 \mathrm{mM}$ compared with isotonic $40 \mathrm{mM} \mathrm{KCl}$-induced contraction. Thus, dentists should consider that the risks of general complications are potentially increased if more than six cartridges of $3 \%$ mepivacaine are used in dental treatment or minor surgery, or over $15 \mathrm{ml}$ of mepivacaine is used at a time for a patient with cardiovascular disease during general anesthesia for oral maxillofacial surgery.

\section{Abbreviations}

HBSS: Hank's balanced salt solution; VOCC: Voltage-operated calcium channel.

\section{Competing interests}

The authors declare that they have no competing interests.

\section{Authors' contributions}

All those listed as authors contributed to the preparation of this manuscript. KS: Study design, animal experiment, data collection, data analysis and writing up of the first draft of the paper. MC, AO: Study design, animal experiment and data collection. MS, MK: study design and data analysis. SJ: Study design, data analysis and editing the paper. All authors have read and approved the final version.

\section{Author details}

${ }^{1}$ Division of Dental Anesthesiology, Department of Reconstructive Oral and Maxillofacial Surgery, School of Dentistry, Iwate Medical University, 1-3-27 Chuo-dori, Morioka, Iwate 020-8505, Japan. ${ }^{2}$ Division of Special Care Dentistry, Department of Developmental Oral Health Science, School of Dentistry, Iwate Medical University, 1-3-27 Chuo-dori, Morioka, Iwate 020-8505, Japan. 
Received: 28 January 2015 Accepted: 6 July 2015

Published online: 14 July 2015

\section{References}

1. Baik JS, Sohn JT, Ok SH, Kim JG, Sung HJ, Park SS, et al. Levobupivacaineinduced contraction of isolated rat aorta is calcium dependent. Can J Physiol Pharmacol. 2011;89:467-76. doi:10.1139/Y11-046.

2. Casati A, Fanelli G, Cedrati V, Berti M, Aldegheri G, Torri G. Pulmonary function changes after interscalene brachial plexus anesthesia with $0.5 \%$ and $0.75 \%$ ropivacaine: a double-blinded comparison with $2 \%$ mepivacaine. Anesth Analg. 1999;88:587-92.

3. Choi YS, Jeong YS, Ok SH, Shin IW, Lee SH, Park JY, et al. The direct effect of levobupivacaine in isolated rat aorta involves lipoxygenase pathway activation and endothelial nitric oxide release. Anesth Analg. 2010;110:341-9. doi:10.1213/ANE.0b013e3181c76f52.

4. Fukuda S, Tsuji T, Murakawa T, Takeshita H, Toda N. Effects of mepivacaine on adrenergic neuroeffector junction of the isolated rabbit aorta. Anesth Analg. 1982;61:756-62.

5. Gherardini G, Samuelson U, Jernbeck J, Aberg B, Sjostrand N. Comparison of isolated rings of human arteries. Acta Anaesthesiol Scand. 1995;39:765-8.

6. Goebel W, Allen G, Randall F. Circulating serum levels of mepivacaine after dental injection. Anesth Prog. 1987;25:52-6.

7. Kawaguchi T, Satoh K, Kuji A, Joh S. Features of distinct contractions induced with a high and low concentration of $\mathrm{KCl}$, noradrenaline, and histamine in swine lingual artery. Naunyn-Schnied Arch Pharmacol. 2010;381:107-20.

8. Meyere P, Flammer J, Lusher TF. Local anesthetic drugs reduce endothelium-dependent relaxations of porcine ciliary arteries. Invest Opthal Vis Sc. 1993;34:2730-6.

9. Mourouzis C, Pantos C, Mourouzis I, Saranteas T, Tesseromatis C, Kostopanagiotou $\mathrm{G}$, et al. Mepivacaine alters vascular responsiveness to vasoconstrictors in aortic rings from normal and aortic-banded rats. Pharmacol Toxicol. 2003;93:269-74.

10. Nakamura K, Toda H, Kakuyama M, Nishiwada M, Yamamoto M, Hatano Y, et al. Direct vascular effect of ropivacaine in femoral artery and vein of the dog. Acta Anaesthesiol Scand. 1993;37:269-73.

11. OK SH, Han JY, Sung HJ, Yang SM, Park J, Kwon SC, et al. Ropivacaineinduced contraction is attenuated by both endothelial nitric oxide and voltage-dependent potassium channels in isolated rat aortae. Biomed Res In. 2013. doi:10.1155/2013/565271.

12. Perlmutter NS, Wilson RA, Edgar SW, Sanders W, Greenberg BH, Tanz R. Vasodilatory effects of lidocaine on epicardial porcine coronary arteries. Pharmacology. 1990;41:280-5.

13. Richard S. Vascular effects of calcium channel antagonists: new evidence. Drugs. 2005;65 Suppl 2:1-10.

14. Satoh K, S Kamada, M Kumagai, M Sato, A Kuji, S Joh. Effect of lidocaine on swine lingual and pulmonary arteries. J Anesthesia. 2015. doi:10.1007/s00540-014-1965-9

15. Stoelting RK. Local anesthetics. Pharmacology \& physiology in anesthetic practice. Philadelphia, USA: Lippincott Williams \& Wilkins; 1999. p. 161-71.

16. Sung HJ, Choi MJ, Ok SH, Lee SH, Hwang IJ, Kim HS, et al. Mepivacaineinduced contraction is attenuated by endothelial nitric oxide release in isolated rat aorta. Can J Physiol Pharmacol. 2012;90:863-72. doi:10.1139/y2012-067.

17. The Internet Drug Index RxLlst. 2015. http://www.rxlist.com/script/main/ art.asp?articlekey=64473. Accessed 27 March 2015

18. Tokinaga Y, Ogawa K, Yu J, Minonishi T, Hatano Y. Mechanism of the ropivacaine-induced increase in intracellular $\mathrm{Ca}^{2+}$ concentration in rat aortic smooth muscle. Acta Anaesthesiol Scand. 2007;51:1155-60.

19. Tucker GT, Moore DC, Bridenbaugh PO, Bridenbaugh LD, Thompson GE. Systemic absorption of mepivacaine in commonly used regional block procedures. Anesthesiology. 1972;37:277-87.

20. Yu J, Tokinaga $Y$, Kuriyama T, Uematsu N. Involvement of $\mathrm{Ca}^{2+}$ sensitization in ropivacaine-induced constriction of rat aortic smooth muscle. Anesthesiology. 2005;103:548-55.

\section{Submit your next manuscript to BioMed Central and take full advantage of:}

- Convenient online submission

- Thorough peer review

- No space constraints or color figure charges

- Immediate publication on acceptance

- Inclusion in PubMed, CAS, Scopus and Google Scholar

- Research which is freely available for redistribution

Submit your manuscript at www.biomedcentral.com/submit 